\title{
Benign Epithelial Neoplasm
}

National Cancer Institute

\section{Source}

National Cancer Institute. Benign Epithelial Neoplasm. NCI Thesaurus. Code C4092.

A neoplasm arising from the epithelial cells. It is characterized by the absence of morphologic features associated with malignancy (severe cytologic atypia, tumor cell necrosis, and high mitotic rate). Benign epithelial neoplasms remain confined to the original site of growth and only rarely metastasize to other anatomic sites. 